https://jom.htp.ac.id/index.php/rmik

\title{
Faktor-Faktor Yang Mempengaruhi Ketidaksesuaian Sensus Harian Rawat Inap Manual Dengan Elektronik Di Rumah Sakit Prima Pekanbaru Pada Periode Agustus-Oktober
}

\author{
Hafizah Bina Pratiwi ${ }^{1}$, Tri Purnama Sari ${ }^{2}$ \\ Program Studi D III Rekam Medis Dan Informasi Kesehatan \\ Sekolah Tinggi IImu Kesehatan Hang Tuah Pekanbaru \\ Email: 1hafizahpratiwi22@gmail.com, ${ }^{2}$ tripurnamasari@htp.ac.id
}

\section{Histori artikel}

Received:

04 Desember 2020

Accepted:

15 Februari 2021

Published:

16 Maret 2021

\begin{abstract}
Abstrak
Setiap rumah sakit wajib melakukan pencatatan dan pelaporan tentang semua kegiatan penyelenggaraan rumah sakit, termasuk kegiatan rawat inap, penyelenggaraan pelaporan merupakan salah satu bagian pelayanan kesehatan yang bertujuan untuk menunjang tercapainya tertib administrasi dalam meningkatkan mutu pelayanan kesehatan, berdasarkan survey awal pada Rumah Sakit Prima Pekanbaru, peneliti menemukan masalah yaitu ktidaksesuaian antara sensus harian rawat inap manual dengan sensus harian rawat inap elektronik. Tujuan penelitian untuk mengetahui faktor-faktor yang mempengaruhi ketidaksesuaian sensus harian rawat inap manual dengan elektronik di Rumah Sakit Prima Pekanbaru pada Periode Agustus-Oktober Tahun 2019.

Metode penelitian yang digunakan adalah deskriptif dengan pendekatan kuantitatif. Penelitian ini dilakukan di unit rekam medis dan ruang perawat rawat inap Rumah Sakit Prima Pekanbaru pada bulan Oktober 2019-Mei 2020, populasinya adalah 130 perawat rawat inap dan bidan diruang rawat inap di Rumah Sakit Prima Pekanbaru dengan teknik purposive sampling. Hasil diperoleh tingkat pengetahuan perawat dan bidan
\end{abstract}


mayoritas masih rendah karena terdapat 40 (57.1\%) responden yang menjawab salah, sikap lebih banyak kategori sikap kurang baik, karena terdapat 38 responden (54.3\%) yang menjawab salah dan tindakan kategori tindakan kurang baik lebih banyak, karena terdapat 38 responden (54.3\%) yang menjawab salah.

Kata Kunci : Pengetahuan, Sikap, Tindakan, Sensus, Manual, Elektronik

\section{PENDAHULUA}

Penyelenggaraan pelaporan merupakan salah satu bagian pelayanan kesehatan yang bertujuan untuk menunjang tercapainya tertib administrasi dalam meningkatkan mutu pelayanan kesehatan. Dalam hal ini diperlukan pencatatan dan pengolahan data secara lengkap dan benar agar menghasilkan informasi yang akurat dan berkesinambungan. Pemanfaatan data laporan ini berhubungan dengan mekanisme alur prosedur pelayanan untuk kepentingan internal dan eksternal rumah sakit terutama untuk mengetahui indikatorindikator pelayanan (Agung Kurniawan, dkk, 2012). Salah satu dasar dalam pembuatan laporan kegiatan rawat inap adalah Sensus Harian Rawat Inap (SHRI) yang kegiatannya dihitung mulai jam 00.00 sampai dengan 24.00 setiap harinya (Rustiyanto, 2010).

Dari penggunaan Sensus Harian Rawat Inap (SHRI) yang tidak maksimal, sehingga keberadaan sensus harian rawat inap hanya sebagai pelengkap atau formalitas, yang sebenarnya bila difungsikan dan di manfaaatkan secara maksimal dapat digunakan untuk pembuatan pelaporan dan mengetahui mutu pelayanan dengan indikator pelayanan rumah sakit sehingga mempermudah pekerjaan petugas (Agung Kurniawan, dkk, 2012).

Rumah Sakit Prima Pekanbaru adalah Rumah Sakit Umum tipe C dengan status kepemilikan PT. Riau Anggun Mandiri yang dipimpin oleh seorang Direktur berada dibawah dan bertanggung jawab kepada pemilik PT. Riau Anggun Mandiri. Rumah Sakit Prima Pekanbaru terletak pada jalur lalulintas utama Kota Pekanbaru di Jalan Bima No. 01 Nangka Ujung/Tuanku Tambusai Kota Pekanbaru yang diresmikan pada tanggal 15 juli 2016 dan dibangun diatas areal seluas 30.000 m2 dengan kapasitas 165 tempat tidur. Rumah Sakit Prima Pekanbaru memiliki 12 ruangan rawat inap, yaitu Bluebells, Gazania, Pointsetia, Sakura, ICU/PICU, HCU/Isolasi, Infant, Perinatologi, VK (kamar bersalin), Tulip, Lavender dan Intermediate Care. Berikut merupakan jumlah kunjungan pasien rawat inap periode AgustusOktober dalam rekapan sensus harian rawat inap manual dan elektronik. 


\section{Tabel 1}

Kunjungan pasien rawat inap periode Agustus-Oktober 2019

\begin{tabular}{lllll}
\hline & Agustus & September & Oktober & Jumlah \\
\hline Manual & 1.304 & 1.415 & 1.471 & 4.190 \\
\hline Elektronik & 1.327 & 1.437 & 1.493 & 4.257
\end{tabular}

Sumber : Rumah Sakit Prima Pekanbaru Tahun 2019

Berdasarkan survey awal, peneliti menemukan masalah yaitu ketidaksesuaian antara sensus harian rawat inap manual dengan sensus harian rawat inap elektronik. Adapun masalah yang dijumpai antara lain pada kunjungan pasien rawat inap periode AgustusOktober dalam rekapan sensus harian rawat inap manual berjumlah 4.190 sedangkan secara elektronik berjumlah 4.257. Hal ini juga terjadi pada petugas sensus harian rawat inap manual tidak konsisten dalam menuliskan jumlah data pasien bahkan terkadang hanya menuliskan data pasiennya saja tetapi tidak menuliskan jumlahnya. Selain itu terkadang data pasien pindahan tidak dimasukkan ke kolom pasien pindahan, melainkan ke kolom pasien masuk. Pembuatan sensus harian rawat inap manual seharusnya dilakukan di jam 00.00 WIB, namun dikarenakan perawat sibuk maka pembuatan sensus tidak pas dilaksanakan dijam 00.00 WIB melainkan terkadang dilaksanakan sebelum jam 00.00 WIB atau bahkan lewat dari jam tersebut. Hal itu dapat dilihat pada tabel 2 berikut ini.

\section{Tabel 2}

Waktu Pengisian Sensus Harian Rawat Inap Manual

\begin{tabular}{lll}
\hline No & Ruangan & Jam Pengisian Sensus \\
\hline 1 & Bluebells & 23.45 WIB \\
\hline 2 & Gazania & 00.00 WIB \\
\hline 3 & Pointsetia & 00.00 WIB \\
\hline 4 & Sakura & 00.15 WIB \\
\hline 5 & ICU/PICU & 00.10 WIB \\
\hline 6 & HCU/Isolasi & 00.05 WIB \\
\hline 8 & Infant & 00.00 WIB \\
\hline 9 & Perinatologi & $00.00 \mathrm{WIB}$ \\
\hline
\end{tabular}




\begin{tabular}{lll}
\hline 10 & Tulip & $23.50 \mathrm{WIB}$ \\
\hline 11 & Lavender & $00.10 \mathrm{WIB}$ \\
\hline 12 & Intermediate Care & $00.00 \mathrm{WIB}$
\end{tabular}

Sumber : Rumah Sakit Prima Pekanbaru Tahun 2020

Tujuan penelitian untuk mengtahui faktor-Faktor yang Mempengaruhi Ketidaksesuaian Sensus Harian Rawat Inap Manual dengan Elektronik di Rumah Sakit Prima Pekanbaru pada Periode Agustus-Oktober Tahun 2019.

\section{METODE}

Metode penelitian yang digunakan adalah deskriptif dengan pendekatan kuantitatif dilakukan di unit rekam medis dan ruang perawat rawat inap Rumah Sakit Prima Pekanbaru pada bulan Oktober 2019-Juli 2020. Populasi dalam penelitian adalah 130 perawat rawat inap dan bidan diruang rawat inap di Rumah Sakit Prima Pekanbaru dengan sampel sebanyak 130 perawat rawat inap dan bidan diruang rawat inap. Pengambilan secara purposive didasarkan pada suatu pertimbangan tertentu yang dibuat oleh peneliti sendiri, berdasarkan ciri-ciri atau sifat-sifat populasi yang sudah diketahui

\section{HASIL}

\section{Hasil Penelitian}

a. Karakteristik Responden

Untuk mempermudah dalam mengidentifikasi responden dalam penelitian ini, maka diperlukan gambaran mengenai karakteristik responden. Adapun gambaran karakteristik responden dalam penelitian ini dibagi menjadi 6 karakteristik, diantaranya sebagai berikut :

\section{Tabel 3}

\section{Karakteristik Responden}

\begin{tabular}{lllll}
\hline No & Kriteria & Keterangan & Frekuensi & Presentase (\%) \\
\hline \multirow{2}{*}{1} & Jenis & Laki-Laki & 21 & $30.0 \%$ \\
& Kelamin & Perempuan & 49 & $70.0 \%$ \\
\hline 2 & Umur & 25-30 Tahun & 32 & $45.7 \%$ \\
\hline
\end{tabular}




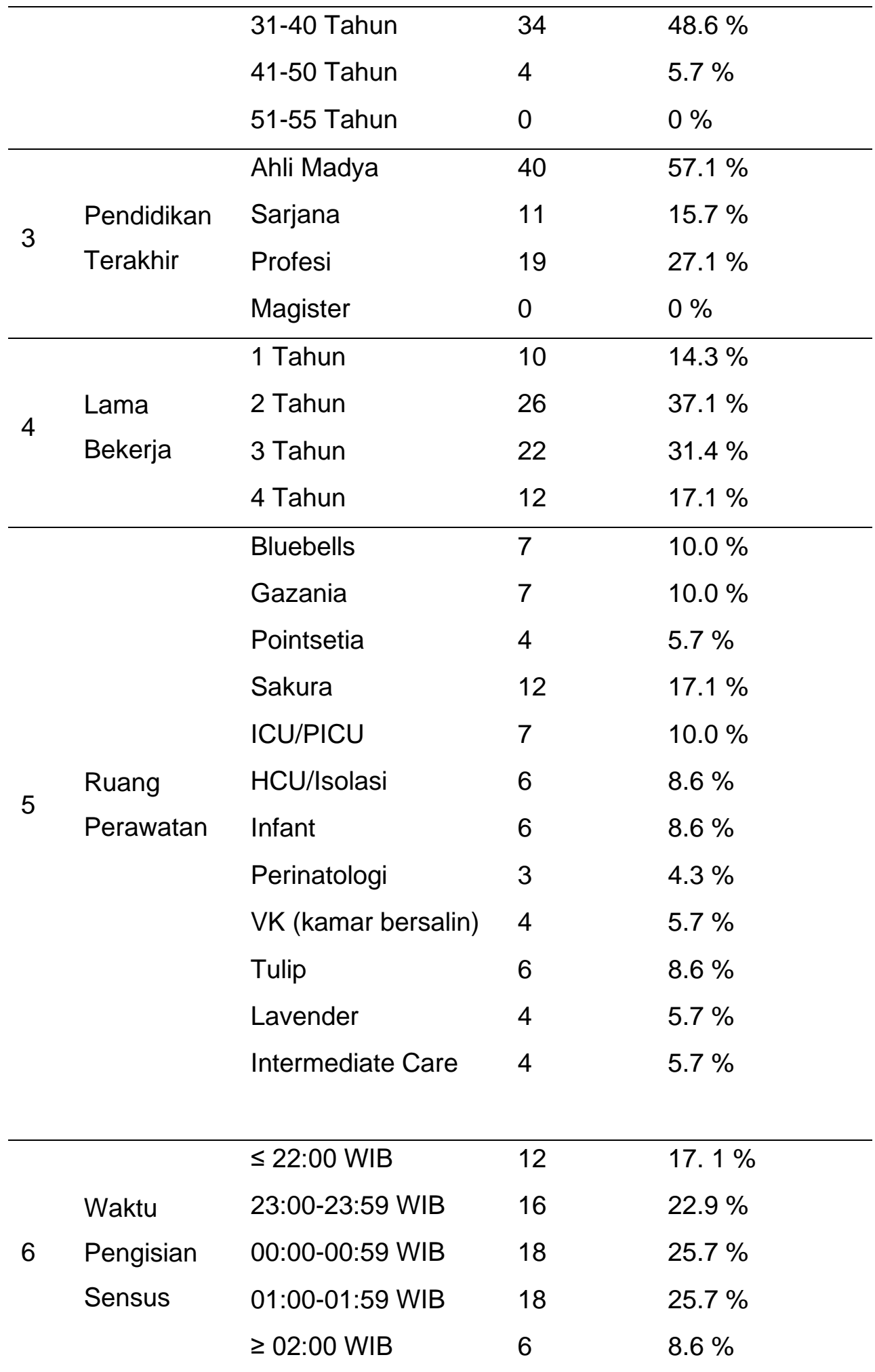

Sumber : Rumah Sakit Prima Pekanbaru Tahun 2020

Berdasarkan tabel 3 di atas, dapat dijelaskan sebagai berikut : 
Dari hasil penelitian frekuensi responden berdasarkan jenis kelamin perawat dan bidan rawat inap di Rumah Sakit Prima Pekanbaru diketahui bahwa sebanyak 21 responden (30.0 \%) berjenis kelamin laki-laki dan sebanyak 49 responden (70.0 \%) berjenis kelamin perempuan. Dari hasil penelitian frekuensi responden berdasarkan umur perawat dan bidan rawat inap di Rumah Sakit Prima Pekanbaru diketahui bahwa sebanyak 32 responden (45.7 \%) berumur 25-30 Tahun, kemudian 34 responden (48.6\%) berumur 31-40 Tahun, selanjutnya 4 responden (5.7\%) berumur 41-50 Tahun, dan sebanyak 0 responden (0\%) berumur 51-55 Tahun.

Dari hasil penelitian frekuensi responden berdasarkan pendidikan terakhir perawat dan bidan rawat inap di Rumah Sakit Prima Pekanbaru diketahui bahwa sebanyak 40 responden (57.1\%) berpendidikan akhir ahli madya, kemudian 11 responden (15.7\%) berpendidikan akhir sarjana, selanjutnya 19 responden $(27.1 \%)$ berpendidikan akhir profesi dan sebanyak 0 responden (0\%) berpendidikan akhir magister.

Dari hasil penelitian frekuensi responden berdasarkan lama bekerja perawat dan bidan rawat inap di Rumah Sakit Prima Pekanbaru diketahui bahwa sebanyak 10 responden (14.3\%) lama bekerja 1 tahun, kemudian 26 responden (37.1\%) lama bekerja 2 tahun, selanjutnya 22 responden (31.4\%) lama bekerja 3 tahun dan sebanyak 12 responden (17.1\%) lama bekerja 4 tahun.

Dari hasil penelitian frekuensi responden berdasarkan ruang perawatan perawat dan bidan rawat inap di Rumah Sakit Prima Pekanbaru diketahui bahwa sebanyak 7 responden (10.0\%) diruang bluebells, sebanyak 7 responden (10.0\%) diruang gazania, sebanyak 4 responden $(5.7 \%)$ diruang pointsetia, sebanyak 12 responden $(17.1 \%)$ diruang sakura, sebanyak 7 responden (10.0\%) diruang ICU/PICU, sebanyak 6 responden (8.6\%) diruang $\mathrm{HCU} /$ Isolasi, sebanyak 6 responden (8.6\%) diruang infant, sebanyak 3 responden $(4.3 \%)$ diruang perinatology, sebanyak 4 responden (5.7\%) diruang VK (kamar bersalin), sebanyak 6 responden $(8.6 \%)$ diruang tulip, sebanyak 4 responden $(5.7 \%)$ diruang lavender dan sebanyak 4 responden (5.7\%) diruang intermediate care.

Dari hasil penelitian frekuensi responden berdasarkan waktu pengisian sensus harian rawat inap perawat dan bidan rawat inap di Rumah Sakit Prima Pekanbaru diketahui bahwa sebanyak 12 responden (17. 1\%) mengisi sensus harian jam $\leq 22: 00 \mathrm{WIB}$, sebanyak 16 responden (22.9\%) mengisi sensus harian jam 23:00 WIB, sebanyak 18 responden (25.7\%) mengisi sensus harian jam 00:00 WIB, sebanyak 18 responden (25.7\%) mengisi sensus 
harian jam 01:00 WIB dan sebanyak 6 responden (8.6\%) mengisi sensus harian jam $\geq 02: 00$ WIB.

b) Analisa Univariat

\section{Tabel 3}

Distribusi Frekuensi Hasil Analisis Univariat

\begin{tabular}{lllll}
\hline No & Kriteria & Keterangan & Frekuensi & Presentase (\%) \\
\hline \multirow{2}{*}{1} & \multirow{2}{*}{ Pengetahuan } & Tinggi & 30 & $42.9 \%$ \\
& & Rendah & 40 & $57.1 \%$ \\
\cline { 3 - 5 } & & Jumlah & $\mathbf{7 0}$ & $\mathbf{1 0 0 \%}$ \\
\hline \multirow{2}{*}{2} & \multirow{2}{*}{ Sikap } & Baik & 32 & $45.7 \%$ \\
& & Kurang Baik & 38 & $54.3 \%$ \\
\cline { 3 - 5 } & & Jumlah & $\mathbf{7 0}$ & $\mathbf{1 0 0 \%}$ \\
\hline \multirow{2}{*}{3} & \multirow{2}{*}{ Tindakan } & Baik & 32 & $45.7 \%$ \\
& & Kurang Baik & 38 & $54.3 \%$ \\
\cline { 3 - 5 } & & Jumlah & $\mathbf{7 0}$ & $\mathbf{1 0 0 \%}$ \\
\hline
\end{tabular}

Sumber : Rumah Sakit Prima Pekanbaru Tahun 2020 
Berdasarkan tabel 3 di atas, dapat dijelaskan sebagai berikut :

Dari tabel tersebut diketahui bahwa dari 70 responden terdapat 30 responden (42.9\%) yang tingkat pengetahuan tinggi dan 40 responden (57.1\%) yang tingkat pengetahuan rendah. Dari tabel tersebut diketahui bahwa responden dengan kategori sikap baik yaitu sebanyak 32 responden (45.7\%) dan kategori sikap kurang baik sebanyak 38 responden (54.3\%). Dari tabel tersebut diketahui bahwa responden dengan kategori tindakan baik terdapat 32 responden (45.7\%) dan kategori tindakan kurang baik 38 responden (54.3\%).

\section{PEMBAHASAN}

\section{Pengetahuan Perawat Terhadap Ketidaksesuaian Sensus Harian Rawat Inap Manual dengan Elektronik di Rumah Sakit Prima Pekanbaru Tahun 2019}

Berdasarkan tabel 4.2 mayoritas tingkat pengetahuan perawat dan bidan rawat inap Rumah Sakit Prima Pekanbaru masih rendah karena terdapat 40 (57.1\%) responden yang menjawab salah sedangkan 30 (42.9\%) responden yang menjawab benar. Sehingga lebih banyak perawat dan bidan yang kurang memahami tentang sensus harian rawat inap.

Hasil penelitian ini sejalan dengan penelitian yang dilakukan oleh Sherly Yana (2014), hasil penelitian tersebut menunjukkan bahwa perawat yang mengisi sensus harian pasien rawat inap dengan tepat $29,6 \%, 70,4 \%$. Perawat yang mempunyai pengetahuan $40,7 \%, 59,3 \%$. Perawat yang mempunyai pengetahuan dan tepat $87,5 \%, 21,1 \%$ dan perawat yang tidak memiliki pengetahuan dan tepat $12,5 \%, 78,9 \%$. Kesimpulan penelitian tersebut adalah pengetahuan perawat masih sangat kurang terhadap ketepatan pengisian sensus harian pasien rawat inap.

Menurut Notoatmodjo (2007), pengetahuan adalah hasil 'tahu', dan ini terjadi setelah seorang melakukan pengindraan terhadap suatu objek tertentu. Pengindraan terjadi melalui pancaindra manusia, yakni: indra penglihatan, pendengaran, penciuman, rasa dan raba. Sebagian besar pengetahuan manusia diperoleh melalui mata dan telinga.

Berdasarkan hasil penelitian ini, peneliti berasumsi bahwa kurangnya pengetahuan tentang sensus harian sangat berpengaruh pada pengisian tiap-tiap item sensus harian rawat inap. Pengisian sensus harian yang salah akan berdampak pada pelaporan rumah sakit.

\section{Sikap Perawat Terhadap Ketidaksesuaian Sensus Harian Rawat Inap Manual dengan Elektronik di Rumah Sakit Prima Pekanbaru Tahun 2019}

Berdasarkan tabel 4.2 diatas mayoritas sikap perawat dan bidan rawat inap Rumah Sakit Prima Pekanbaru kategori sikap kurang baik, karena terdapat 38 responden (54.3\%) yang menjawab salah sedangkan 32 responden (45.7\%) yang menjawab benar. 
Menurut Notoatmodjo (2007), sikap merupakan reaksi atau respons seseorang yang masih tertutup terhadap suatu stimulus atau objek. Sikap itu tidak dapat langsung dilihat, tetapi hanya dapat ditafsirkan terlebih dahulu dari perilaku yang tertutup. Sikap secara nyata menunjukkan konotasi adanya kesesuaian reaksi terhadap stimulus tertentu. Dalam kehidupan sehari-hari merupakan reaksi yang bersifat emosional terhadap stimulus sosial.

Berdasarkan hasil penelitian ini, peneliti berasumsi bahwa sensus harian harus tetap dibuat baik ada pasien pindahan, pasien dipindahkan, pasien meninggal maupun tidak ada pasien. Sikap yang baik akan menghasilkan pekerjaan yang baik.

\section{Tindakan Perawat Terhadap Ketidaksesuaian Sensus Harian Rawat Inap Manual dengan Elektronik di Rumah Sakit Prima Pekanbaru Tahun 2019}

Berdasarkan tabel 4.4 diatas mayoritas tindakan perawat dan bidan rawat inap Rumah Sakit Prima Pekanbaru kategori tindakan kurang baik, karena terdapat 38 responden (54.3\%) yang menjawab salah sedangkan 32 responden (45.7\%) yang menjawab benar.

Menurut Notoatmodjo (2007), suatu sikap belum otomatis terwujud dalam suatu tindakan (overt behaviour). Untuk terwujudnya sikap menjadi suatu perbedaan nyata diperlukan faktor pendukung atau suatu kondisi yang memungkinkan, antara lain adalah fasilitas. Disamping itu faktor fasilitas juga diperlukan faktor dukungan (support) dari pihak lain. Tingkat-tingkat praktik atau tindakan yaitu, persepsi, respon terpimpin, mekanisme, adaptasi. Pengukuran juga dapat dilakukan secara langsung, yakni dengan mengobservasi tindakan atau kegiatan responden. Berdasarkan hasil penelitian ini, peneliti berasumsi bahwa data sensus harian rawat inap yang tidak akurat sesuai aslinya akan berpengaruh pada pelaporan rumah sakit dan akan mempersulit petugas pelaporan rumah sakit.

\section{KESIMPULAN}

1. Tingkat pengetahuan perawat dan bidan rawat inap Rumah Sakit Prima Pekanbaru Tahun 2020 mayoritas masih rendah karena terdapat 40 (57.1\%) responden yang menjawab salah sedangkan 30 (42.9\%) responden yang menjawab benar. Sehingga lebih banyak perawat dan bidan yang kurang memahami tentang sensus harian rawat inap.

2. Sikap perawat dan bidan rawat inap Rumah Sakit Prima Pekanbaru Tahun 2020 lebih banyak kategori sikap kurang baik, karena terdapat 38 responden (54.3\%) yang menjawab salah sedangkan 32 responden (45.7\%) yang menjawab benar.

3. Tindakan perawat dan bidan rawat inap Rumah Sakit Prima Pekanbaru Tahun 2020 dalam kategori tindakan kurang baik lebih banyak, karena terdapat 38 responden 
(54.3\%) yang menjawab salah sedangkan 32 responden (45.7\%) yang menjawab benar.

\section{SARAN}

1. Sebaiknya perawat dan bidan rawat inap Rumah Sakit Prima Pekanbaru mengikuti kegiatan seminar atau pelatihan tentang sensus harian rawat inap sehingga mereka dapat mengetahui bahwa pengisian sensus yang baik dan benar akan meningkatkan mutu rumah sakit.

2. Sebaiknya sikap perawat dan bidan Rumah Sakit Prima Pekanbaru dalam membuat sensus harian rawat inap perlu ditingkatkan lagi. Evaluasi pengisian sensus harian rawat inap juga perlu dilakukan untuk meminimalisir terjadinya sikap yang kurang baik. Sikap yang baik akan menghasilkan pekerjaan yang baik.

3. Sebaiknya tindakan perawat dan bidan dalam membuat sensus harian rawat inap perlu ditingkatkan lagi agar memudahakan petugas pelaporan rumah sakit dan dapat meningkatkan mutu rumah sakit.

\section{DAFTAR PUSTAKA}

DepKes RI. (2005). Petunjuk Pengisian, Pengolahan, dan Penyajian Data Rumah Sakit. Jakarta: DIRJEN YANMED.

(2006). Pedoman Penyelenggaraan dan Prosedur Rekam Medis Rumah Sakit di Indonesia Revisi II. Jakarta: DIRJEN YANMED.

Dewi, Deasy Rosmala; Gussa Azizah, Retno Juwita. (2014). "Tinjauan Keakuratan Data pada Sensus Harian Rawat Inap Di Rumah Sakit Khusus Bedah Banjarmasin Siaga". Jurkessia,

Vol.

IV,No.3.(Online)https://journal.stikeshb.ac.id/index.php/jurkessia/article/view/40/38

[Diakses pada tanggal 20 Desember 2019]

Harahap, Erwin Syahputra. (2011). "Faktor-Faktor Yang Mempengaruhi Pelaksanaan Sensus Harian Pasien Rawat Inap Di RSUD Dr. Adnan WD Payakumbuh Tahun 2011. (Online) https://www.scribd.com/document/366161053/Lembaran-Kuesioner-docx][Diakses pada tanggal 28 Desember 2019

Hatta, Gemala R. (2010). Pedoman Manajemen Informasi Kesehatan di Sarana Pelayanan Kesehatan. UI-Press.Jakarta

Herlambang, Susatyo. (2016). Manajemen Pelayanan Kesehatan Rumah Sakit. Yogyakarta: Gosyen Publishing. 
Kurniawan, Agung; Tri Lestari dan Rohmadi. (2012). "Analisis Pemanfaatan Data Sensus Harian Rawat Inap Untuk Pelaporan Indikator Pelayanan Rawat Inap di Rumah Sakit Umum Dr. Soeroto Ngawi”. Jurnal Kesehatan. ISSN 1979-9551 Vol. IV, No. 2.(Online)https://ejurnal.stikesmhk.ac.id/index.php/rm/article/view/10/8 [Diakses pada tanggal 20 Desember 2019]

Notoatmodjo, S. (2005). Metodologi Penelitian Kesehatan. Jakarta : Rineka Cipta

Notoatmodjo, S. (2007). Kesehatan Masyarakat IImu dan Seni. Jakarta : Rineka Cipta. (2010). Metodologi Penelitian Kesehatan. Jakarta : Rineka Cipta (2018). Metodologi Penelitian Kesehatan. Jakarta : Rineka Cipta

PERMENKES RI Nomor 269/MENKES/Per/III.2008, Tentang Rekam Medis, Jakarta.

Permenkes RI Nomor 1171/MENKES/PER/VI/2011 Tentang Sistem Informasi Rumah Sakit, Jakarta.

Republik Indonesia. (2009). Undang-Undang RI Nomor 44 Tahun 2009 tentang Rumah Sakit Rustiyanto E. (2010). Statistik Rumah Sakit Untuk Penngambilan Keputusan. Yogyakarta: Graha IImu.

Sudra, Rano Indradi. 2010. "Statistik Rumah Sakit dari Sensus Pasien \& Grafik BarberJohnson Hingga Statistik Kematian \& Otopsi", Yogyakarta

Sugiyono. (2004). Metode Penelitian. Bandung: Alfabeta.

Yana, Sherly. (2014). Pengaruh Pengetahuan Perawat Terhadap Ketepatan Pengisian Sensus Harian Rawat Inap di RSUD Batara Guru Belopa Sulawesi Selatan. (Online) https://digilib.esaunggul.ac.id/pengaruh-pengetahuan-perawat-terhadapketepatanpengisian-sensus-harian-pasien-rawat-inap-di-rsud-batara-gurubelopasulawesi-selatan-3436.html [Diakses pada tanggal 28 Desember 2019]. 